$\pm N /$

Global Journals Inc.

(2)

\title{
Analysis of the Influence of Biomass Addition in Coal Mixture for Metallurgical Coke Production
}

\author{
By Alex M. A. Campos \& Paulo S. Assis
}

Abstract- Metallurgical coke is a common material used for hot metal production in blast furnaces. In addition to the fuel function, it has a physical assignment, supporting the load inside the reactor, and chemical, supplying carbon to hot metal. However, due to growing discourse on environmental issues, the production of hot metal via coke blast furnace has been in evidence. This process is responsible for about $70 \%$ of $\mathrm{CO}_{2}$ emissions in steelmaking. On the other hand, biomasses are materials that are available in different ways in nature and considered neutral in $\mathrm{CO}_{2}$ emissions since they absorb this gas and release oxygen in the photosynthesis process. Thus, a viable alternative in the short term is the partial replacement of the coal used in coke production with biomass, which would generate environmental gains, and guarantee the sustainable production. Therefore, this work aims to show several published researches using biomass in coke production. The effects that biomass has on the properties of coke will be emphasized, and at the end, an environmental analysis will be shown with the possible use of biomass. It will be possible to see that it is possible to substitute between 2 and $10 \%$ of the coal for biomass, producing coke with the characteristics required in the blast furnace.

Keywords: biomass; coke; cokemaking; ironmaking; steelmaking.

GJRE-E Classification: FOR Code: 290899

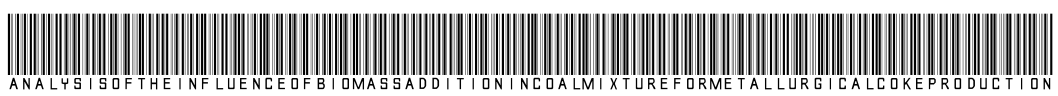

Strictly as per the compliance and regulations of:

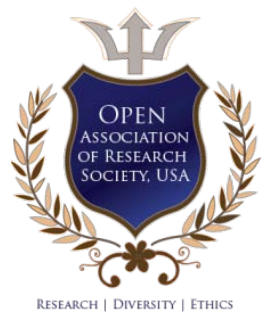

(C) 2021. Alex M. A. Campos \& Paulo S. Assis. This is a research/review paper, distributed under the terms of the Creative Commons Attribution-Noncommercial 3.0 Unported License http://creativecommons.org/licenses/by-nc/3.0/), permitting all noncommercial use, distribution, and reproduction in any medium, provided the original work is properly cited. 


\title{
Analysis of the Influence of Biomass Addition in Coal Mixture for Metallurgical Coke Production
}

\author{
Alex M. A. Campos ${ }^{\alpha} \&$ Paulo S. Assis ${ }^{\sigma}$
}

\begin{abstract}
Metallurgical coke is a common material used for hot metal production in blast furnaces. In addition to the fuel function, it has a physical assignment, supporting the load inside the reactor, and chemical, supplying carbon to hot metal. However, due to growing discourse on environmental issues, the production of hot metal via coke blast furnace has been in evidence. This process is responsible for about $70 \%$ of $\mathrm{CO}_{2}$ emissions in steelmaking. On the other hand, biomasses are materials that are available in different ways in nature and considered neutral in $\mathrm{CO}_{2}$ emissions since they absorb this gas and release oxygen in the photosynthesis process. Thus, a viable alternative in the short term is the partial replacement of the coal used in coke production with biomass, which would generate environmental gains, and guarantee the sustainable production. Therefore, this work aims to show several published researches using biomass in coke production. The effects that biomass has on the properties of coke will be emphasized, and at the end, an environmental analysis will be shown with the possible use of biomass. It will be possible to see that it is possible to substitute between 2 and $10 \%$ of the coal for biomass, producing coke with the characteristics required in the blast furnace.
\end{abstract}

Keywords: biomass; coke; cokemaking; ironmaking; steelmaking.

\section{INTRODUCTION}

S. teelmaking processes have a high-energy consumption and coal is the main source, and steel production has been responsible for $7-9 \%$ of $\mathrm{CO}_{2}$ emissions in recent years, largely due to the use of fossil fuels. To produce $1.85 \mathrm{t}$ of steelis emitted around $3.3 \mathrm{t}$ of $\mathrm{CO}_{2}$, which puts the steel sector in the spotlight of the environmental discussion (Holappa, 2020).

In the steel industry, the process that emits more $\mathrm{CO}_{2}$ is the blast furnace (about $70 \%$ ) due to the high consumption of fossil fuels, including coke (Orth, 2007). For this reason, efforts to reduce $\mathrm{CO}_{2}$ emissions must focus on the blast furnace, with solutions to minimize the effects of burning coke and coal. In addition, coke, as well as coal, represents about $40 \%$ of the final cost of steel, which makes producers look for sustainable alternatives to compose the coke mixture.

For Noldin (2005), the inevitable dependence on the use of metallurgical coke puts conventional blast furnaces in a difficult situation, due to environmental restrictions and to the global scarcity and exorbitant prices of this raw material. This new scenario of shortages and high coke prices was created by the

Author a: Khambar Tursunbaeve.

e-mail:alexcampos88@yahoo.com.br huge demand for steel in China, which is the largest coke exporter.

One of the alternatives that has been studied, mainly to mitigate environmental impacts, is the replacement of part of coal used in coke making by biomass. Thus, there would be a reduction in $\mathrm{CO}_{2}$ emissions, since biomass can be considered neutral in emissions as it captures this from the atmosphere during photosynthesis process. In addition, the photosynthesis can generate a drop in the cost of steel production, since the price difference between coal and biomass can be considerable.

Biomass is all vegetable or animal organic matter that is used in the production of energy. Like other renewable sources, biomass can be considered neutral in $\mathrm{CO}_{2}$ emissions. Compared to fossil fuels, biomass has a higher volatile content, less carbon and a lower calorific value, lower sulfur content, lower ash content, higher hydrogen content, and may be interesting for its use in the steel industry. For Quan (2016), compared to plastic and other waste, biomass is a source of perspective for the replacement of fossil fuels in the future, as it is abundant, renewable, clean, and carbon neutral.

The great gain in substituting part of coal for biomass in metallurgical coke production is in the environmental. What makes biomass neutral in $\mathrm{CO}_{2}$ emissions is the so-called carbon cycle. Burning biomass causes the release of $\mathrm{CO}_{2}$ into the atmosphere. However, plants, through photosynthesis, transform $\mathrm{CO}_{2}$ and water into carbohydrates, which make up their living mass, releasing oxygen. Thus, the use of biomass, not in a predatory way, does not change the average composition of the atmosphere over time (Silva, 2008). In this approach, the GGE balance is negative, which means that the overall sequestration of $\mathrm{CO}_{2}$ from the atmosphere for the cultivation of biomass is greater than the $\mathrm{CO}_{2}$ emissions during the production process. In addition, the low sulfur content in biomass results in very low emissions of SOx. This can result in the use of biomass to supply the energy and reducers necessary for the production of hot metal, guaranteeing an ecologically correct operation.

Studies involving the use of biomass in steelmaking processes have been gaining strength due to the factors mentioned. Particularly in the cokemaking, most studies involve charcoal fines or wood residues such as sawdust and bark. All studies in this line show 
that when adding biomass to coal mixture for coke production, there is a drop in coke quality. However, there are results that, in a certain limit, are viable and can bring economic and environmental gains without considerable loss of coke quality.

In view of these facts, this work aims to discuss the use of biomass, replacing fossil fuels, in coal mixtures used in cokemaking for metallurgical coke production. The use of biomass in the coke oven will be shown, presenting some works that have been developed around the world and making a critical analysis, pointing out the pros and cons of this use. Some environmental aspects of the use of biomass will also be discussed. Finally, some suggestions will be given for future work on the use of biomass in steelmaking processes.

\section{Development}

In the development of this work, some important concepts about coke, its production, about biomass, and its application in the production of metallurgical coke will be shown. At the end, an environmental analysis, an actualization of political discourses, and simulation of possible scenarios that can be reached by steel companies will be made.

\section{a) Coke Production}

The coke production process was developed in England in the late $16^{\text {th }}$ century, and at first, the coke produced was not used in hot metal production, that was basically produced in charcoal blast furnaces. After the industrial revolution, coke became an essential fuel for hot metal and steel production, increasing the productivity of blast furnaces (Ricketts, 2000).

Metallurgical coke is produced through coal distillation at temperatures of approximately $1000^{\circ} \mathrm{C}$. This process is called cokeification, and occurs in batteries containing retorts (long, high and strict) in the case of By-product coke ovens or in chambers when the Heat Recovery coke oven is used (Mourão, 2011).

The coke produced must have high resistance properties to avoid degradation insides blast furnace, as well as containing high carbon content, low reactivity, low ash, and sulfur content.

Steelmakers have the coke oven integrated into the steelmaking plant, but there are also independent producers whose main customers are steelmakers. In coke plants, $1000 \mathrm{~kg}$ of coal produce around (AISE, 1999):

- $750 \mathrm{~kg}$ of coke $(690 \mathrm{~kg}$ of blast furnace coke, and $60 \mathrm{~kg}$ of coke breeze);

- $36 \mathrm{~kg}$ of tar (which includes: $2.5 \mathrm{~kg}$ of naphthalene, $15 \mathrm{~kg}$ of light oils, and $18.5 \mathrm{~kg}$ of tar);

- $7.28 \mathrm{~kg}$ of total benzol (comprising: $5.35 \mathrm{~kg}$ of benzene, $1.25 \mathrm{~kg}$ of toluene, and $0.68 \mathrm{~kg}$ of xylene);

- $12 \mathrm{~kg}$ of ammonium sulfate.

World steel production in 2019 was about 1.6 billion tonnes, most of this production is via coke blast furnace, that is, a large production is required to serve steel mills. As can be seen in figure 1, world coke production in 2018 reached 629 million tons.

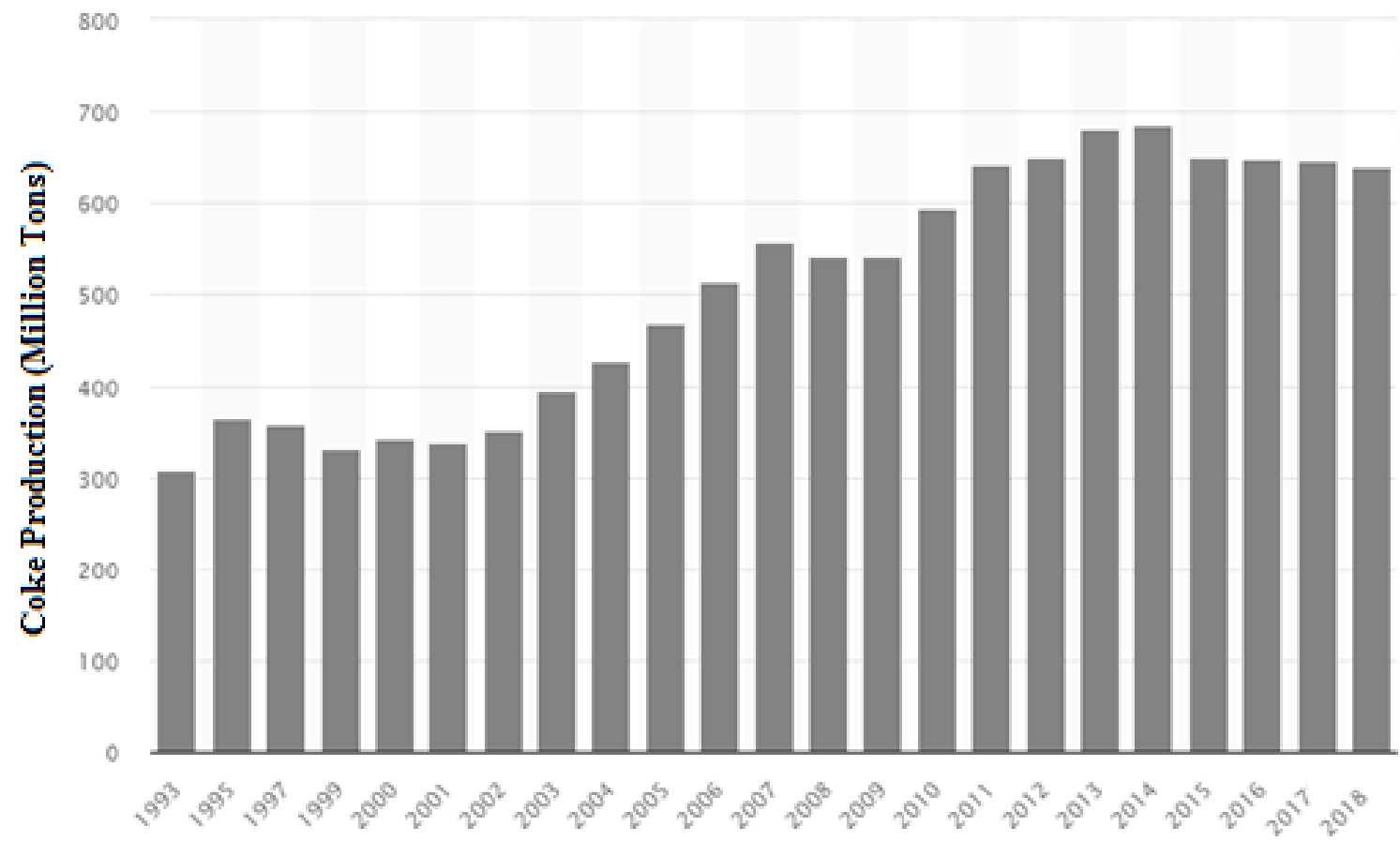

Figure 1: World Coke Production (Garside, 20019) 
In the blast furnace, coke has some main functions, including:

- Acts as a generator of reducing gases: its gasification generates reducing gases that are responsible for changing iron oxides to metallic iron.

- Acts as a combustible material: as coke burning reactions are exothermic, they generate heat for reactions to reduce oxides and fuse metallic iron.

- Enriching hot metal carbon content, acting as hot metal fuel.

- And finally, it supports the layers of metallic charge, thus allowing permeable beds to be generated for the passage of upward gases.

To perform the functions listed in the blast furnace, coke must present (Rizzo, 2009):

- Maximum carbon content and minimum ash, sulfur, and moisture content.

- Adequate reactivity values for $\mathrm{CO}_{2}$ and $\mathrm{H}_{2} \mathrm{O}$.

- Particle size range, when loaded in the blast furnace, suitable and controlled.

- Good resistance to mechanical, thermal, and chemical degradation.

Some quality parameters are necessary to analyze the quality of coke in the blast furnace, including the chemical, physical and metallurgical porperties. Table 1 shows expected values for coke according to each property.

Table 1: Coke properties for blast furnace uses (Rizzo, 2009)

\begin{tabular}{|c|c|}
\hline Properties & Coke Quality \\
\hline Moisture & $<6,0 \%$ \\
\hline Fixed Carbon & $65-75 \%$ \\
\hline Ash & $<10,5 \%$ \\
\hline Volatiles & $<1,2 \%$ \\
\hline Sulfur & $<07 \%$ \\
\hline Phosphor & $<0,045 \%$ \\
\hline Alkalis & $<0,35 \%$ \\
\hline Density & $180-350 \mathrm{~kg} / \mathrm{m}^{3}$ \\
\hline Drum Index (150/15) & $>85 \%$ \\
\hline CSR & $>65,5 \%$ \\
\hline CRI & $21 \mathrm{a} 25,5 \%$ \\
\hline Compression Strength & $130-160 \mathrm{kgf} / \mathrm{cm}^{3}$ \\
\hline Particle Size & $45-60 \mathrm{~mm}$ \\
\hline
\end{tabular}

These variables presented will affect the operational control of the blast furnace, the permeability of the load, iron ore reduction reactions, and characteristics of hot metal produced. Many tests are done with coke before being used in a blast furnace. The most important ones are CRI (Coke Reactivity index), CSR (Coke Strength after Reaction), DI (Drum Index), average size, compression resistance, among others. In addition, it is important to characterization the materials that will compose the mixtures, so that it is possible to predict the coke quality.

\section{b) Biomasses}

Biomass can be defined as the total mass of organic substances that occur in a habitat. The forms of biomass on our planet are many, and varied. According to their origin, biomasses are divided into four basic categories defined by Rocha (2011) as:

- Crops for energy production - grown mainly to generate energy;

- Post-harvest waste - waste generated during harvest such as straw, wood waste and natural waste. They are interesting because they have low cost.

- Organic by-products - are residues from the industrial processing of biomass, livestock manure, vegetable fibers, etc.;

- Organic waste - includes sewage effluents, domestic, commercial, and industrial waste.

To use biomass in the steelmaking process, the most interesting categories are harvest for energy, in the case of charcoal, and the post-harvest residues, which are the types of biomass considered in this work. The amount of waste after harvest can reach $50 \%$ of production by weight, and in some cases, such as coffee and soy. Table 2 shows the production of crops in 2019, according to the Food and Agricultural Organization of the United Nations (FAO), and the calculation of possible quantities of post-harvest waste generated according to Carvalho (1992).

Table 2: World biomass production (FAO, 2019)

\begin{tabular}{|c|c|c|}
\hline Biomasses & $\begin{array}{c}\text { Production } \\
\left(10^{3} \mathrm{t}\right)\end{array}$ & $\begin{array}{c}\text { Residues }^{\star} \\
\left(10^{3} \mathrm{t}\right)\end{array}$ \\
\hline Sugar cane & $1.949 .310,1$ & $633.525,8$ \\
\hline Soya & $333.671,7$ & $166.835,5$ \\
\hline Maize & $1.148 .487,3$ & $492.701,1$ \\
\hline Coffee & $10.035,6$ & $5.017,8$ \\
\hline Rice & $755.473,8$ & $151.094,8$ \\
\hline
\end{tabular}

${ }^{*}$ Calculated according to CARVALHO, 1992.

The use of biomass is the oldest method for providing energy. However, the use of biomass as a renewable energy source must undergo a development of technology. In addition to the positive environmental effects of using biomass as a fuel, it can be said that greenhouse gases are emitted during their burning, but the amount is the same produced by the natural decomposition process. In addition, in the case of plant biomass, during its growth, carbon dioxide is consumed during photosynthesis, which can generate a positive balance when analyzing the emission (Campos, 2018).

In photosynthesis process $\mathrm{CO}_{2}$ capture from the atmosphere is reduced to organic compounds, and the 
more the phytosystem is growing, the more carbon it removes from the atmosphere, calling "carbon sequestration". In growing ecosystems, such as soybean, cotton, and castor plantations, among others, the removal of carbon dioxide from the air via photosynthesis is high, reaching up to $35 \mathrm{t} \mathrm{CO}_{2} /$ hectare (EMBRAPA, 2007).

In addition to chemical properties, biomasses differ in their physical properties like lower density, and greater porosity. To analyze economic aspects, is necessary evaluate two restrictions. First, it is necessary to know whether the biomass to be exploited energetically has no other uses (industrial or food). Second, if all the costs of the biomass harvested are compatible with the energy benefits and comparable with other fuels. Finally, technological restrictions are due to the existence or not of reliable processes and operations to convert biomass into fuels.

c) Influence of Biomass Addition in Coal mixtures for Cokemaking

The use of biomass in the industrial sector has been gaining ground for presenting unique properties such as renewability, carbon neutrality, low sulfur content, low ash content, high reactivity, among others, which, when properly treated, are able to replace fossil fuel in the production of coke, for example (Mousa, 2016). For the steel industry, it is not advantageous to use biomass in its raw state, and therefore, it is necessary to convert them through processes such as torrefaction, pyrolysis, combustion, etc.

Biomass, according to Babich (2019), can be used in steel mills in three different ways, such as injection into blast furnaces or electric arc furnaces, incorporation into cargo materials or into the mixture of coal for coke or generation of reducing gas.

Silva (2008) performed an analysis of biomass in coal mixture using a pilot furnace with concentrations of $2 \%, 4 \%$, and $6 \%$ with different types of biomass such as rice husk, soy, coconut, macadamia husk, coffee husk, and charcoal. The biomasses with concentrations of $6 \%$, presented a good behavior due to their presence does not alter the swelling index and to reduce the sulfur content and its fluidity.

The calcined rice husk with a $6 \%$ concentration was used in an industrial test. Its addition to the coal mixture increased the average size of the coke, without changing its mechanical resistance. In figure 2, it is possible to observe a comparison of the data obtained on the industrial scale compared to the standard coke produced. It is possible to notice that there were no changes in the $\mathrm{Dl}$, its reactivity was maintained and the ash content had an increase due to the presence of silicon oxides in the rice husk.

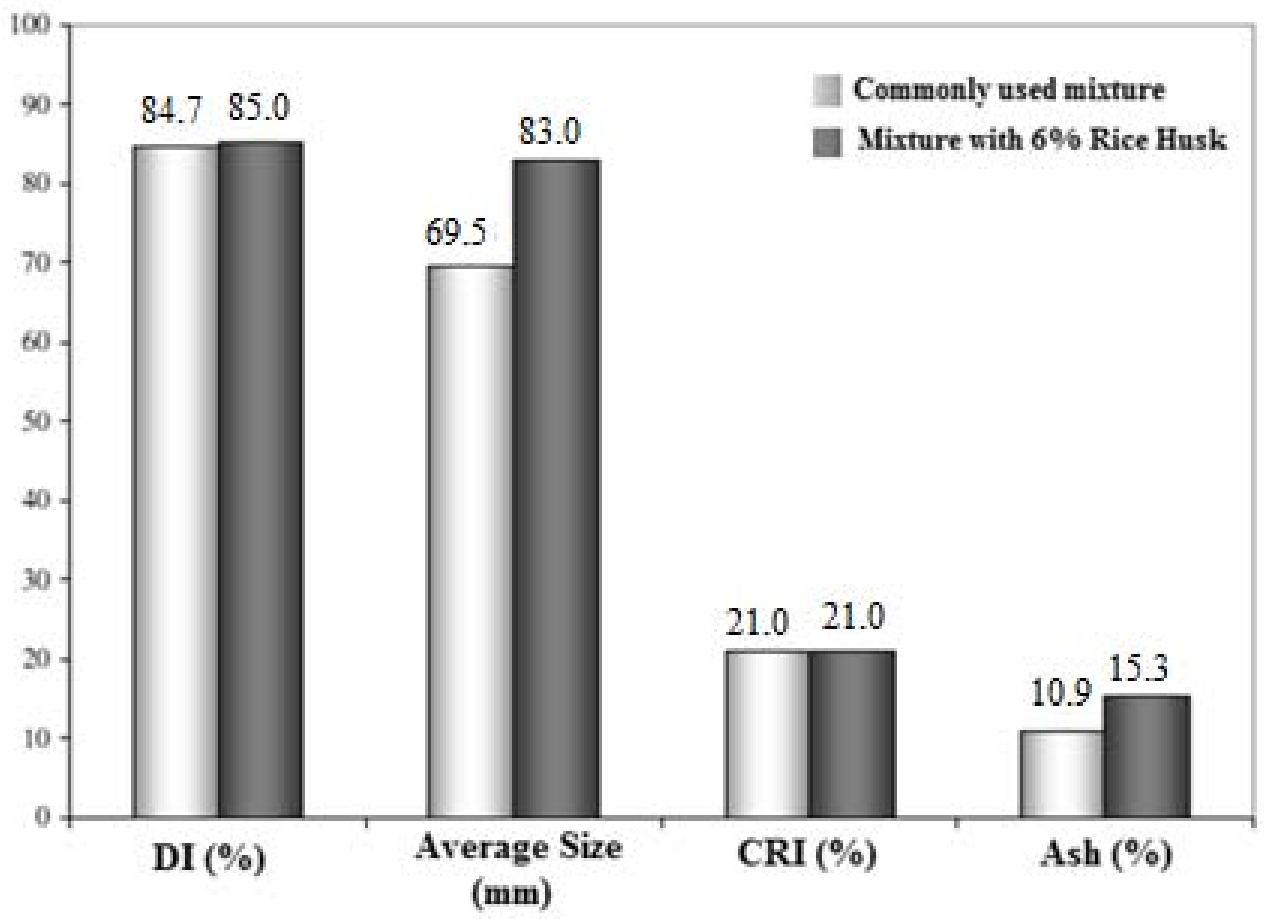

Figure 2: Industrial test of the use of $6 \%$ rice husk in the coke mixture (Silva, 2008)

A drop in the mechanical resistance of the coke was observed when adding biomass. The Main effects, and interaction analyzes between the addition of biomass and granulometry factors allows to conclude that the coarse grinder aggravates the drop in DI in relation to biomass with smaller particle size for the same level of addition. In figure 3 is possible to see a research using charcoal with different particle sizes. 


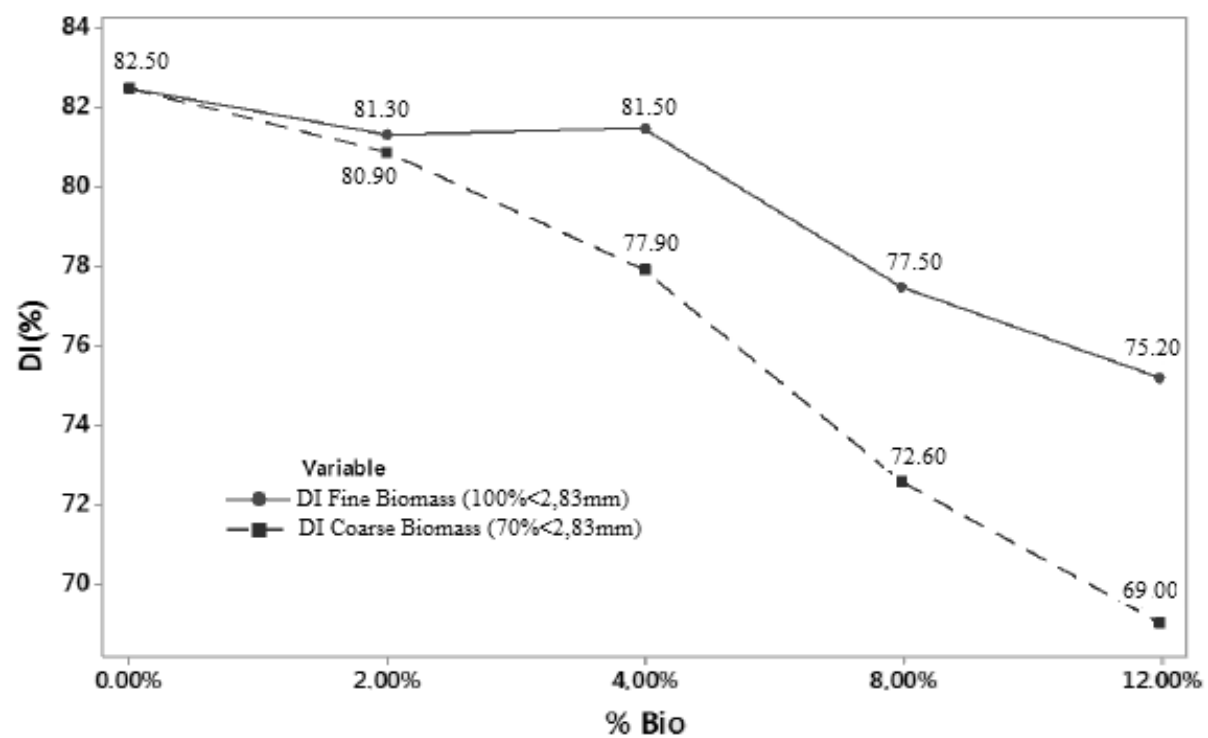

Figure 3: Evolution of DI with the addition of biomass (Silva, 2016a)

The drop in DI can be attributed to the increase in the inert content of the mixture, decreasing its coking power. According to Kubota (2008), the greater participation of aggregates above $1.5 \mathrm{~mm}$ increases the concentration and propagation of cracks, depreciating the mechanical resistance of the coke.

Carvalho (2021) found an inverse and direct relationship between biomass participation in CSR and
$\mathrm{CRI}$, respectively. In figure 4 , it is possible to notice that the addition of $2 \%$ of sawdust generated a drop of $3.9 \%$ in the CSR and an increase of $0.63 \%$ in CRI. In the addition of $5 \%$, there was a significant drop of $12.29 \%$ in CSR and an increase of $2.54 \%$ in CRI.

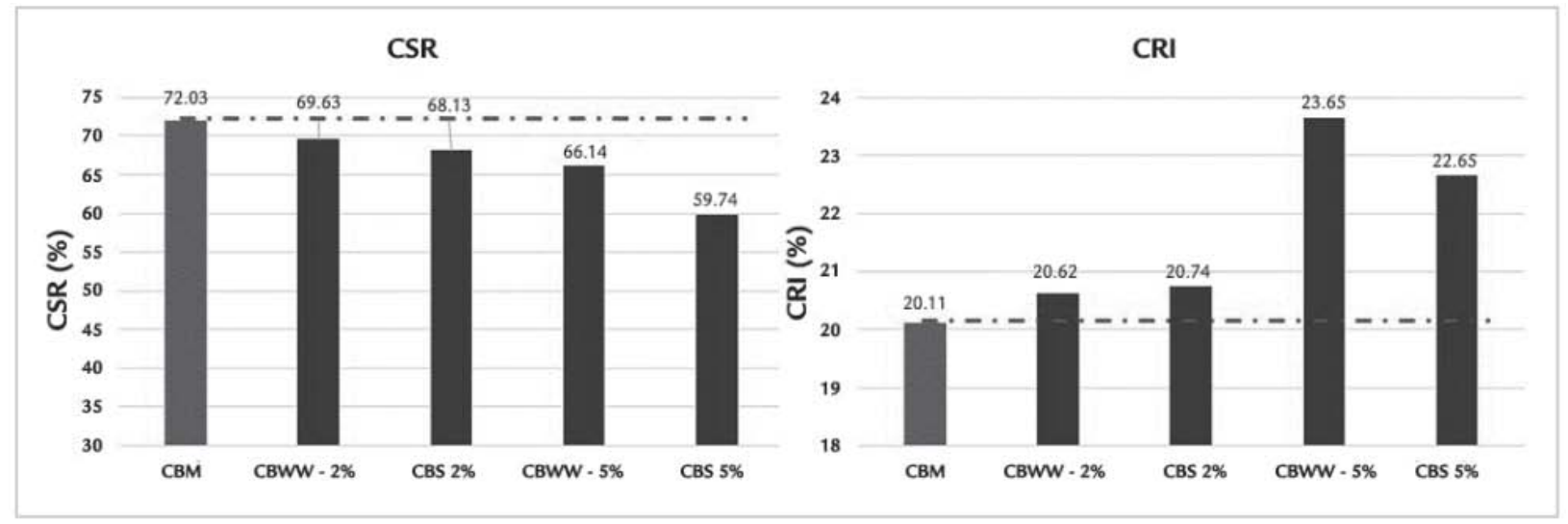

Figure 4: CSR e CRI of coke produced with wood and sawdust (Carvalho, 2021)

When compared to sawdust $2 \%$, wood $2 \%$ showed a lower drop in CSR values (1.5\%) and a smaller increase in CRI values (0.12 \%). Wood $5 \%$ showed a higher CSR value (66.14\%) compared to the sawdust level 5\% (59.74 \%), with an increase in CRI to $23.65 \%$ against $22.65 \%$ of sawdust.

Another important point is the sulfur content, which is not desired in hot metal production. Liziero (2017) concludes in his work that whenever biomass is added to the coal mixture, there will be a decrease in the sulfur content of the mixture, as shown in figure 5. 


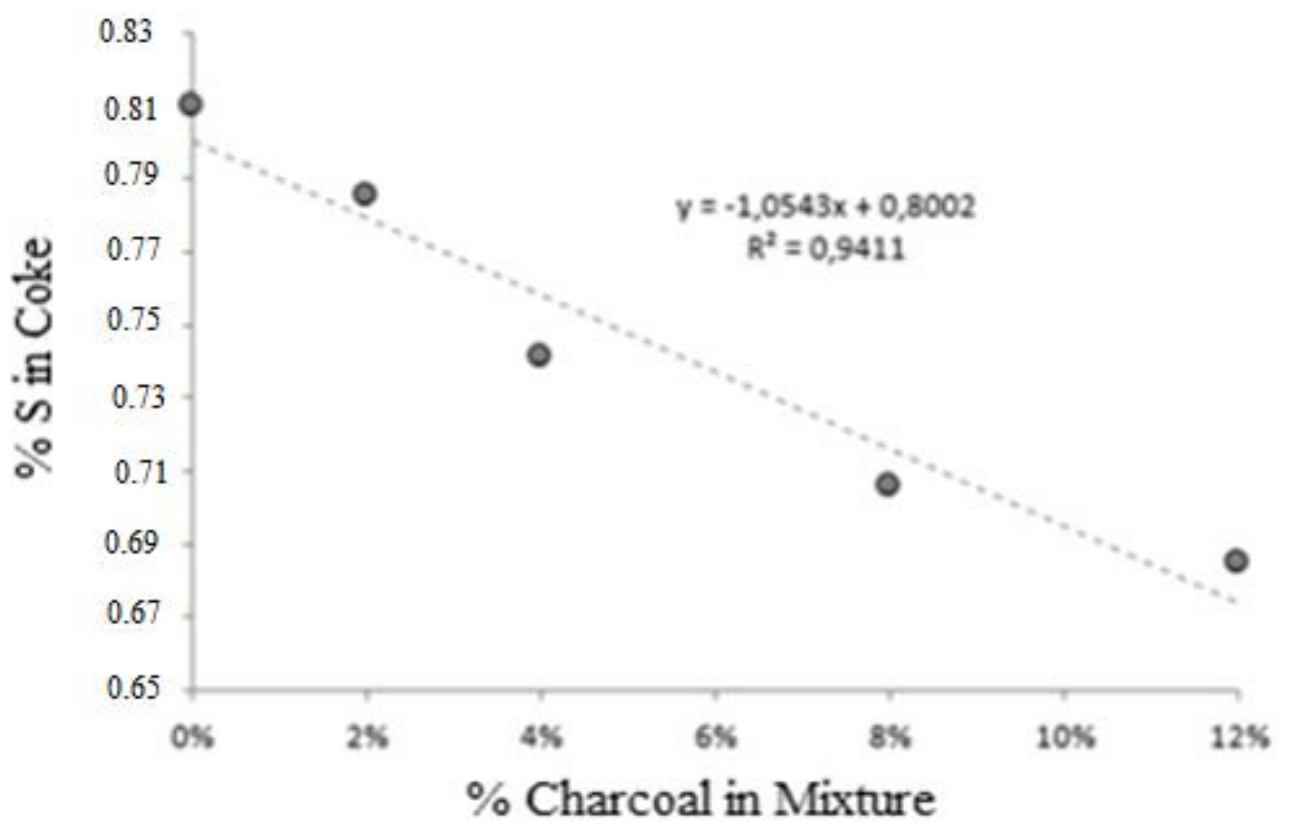

Figure 5: Effect of sulfur content in coke with biomass addition (Liziero,2017)

Regarding the ash content of coke with the in biomass can be seen in the dispersion diagram addition of biomass, a linear decrease with the increase shown in figure 6.

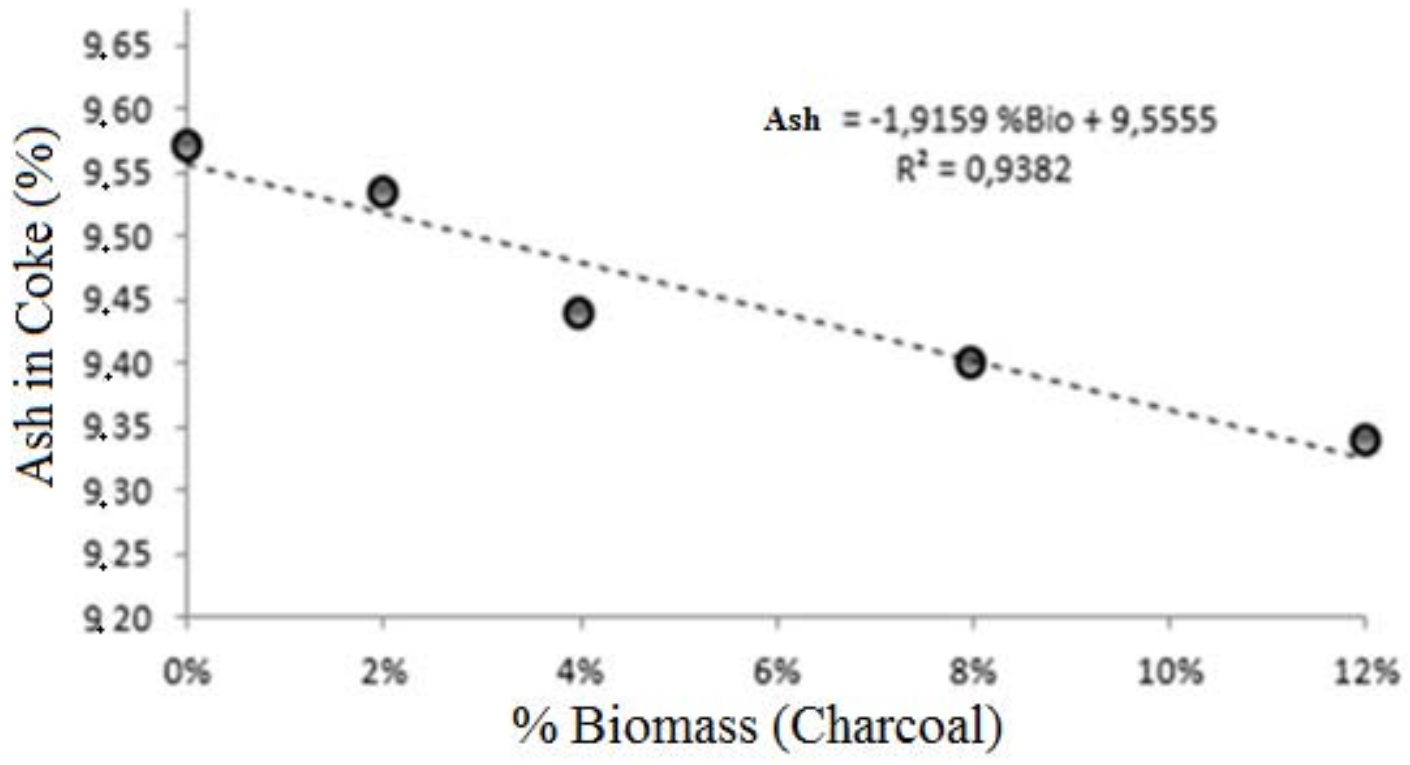

Figure 6: Ash behavior with biomass addition (Silva, 2016).

This behavior is expected since the ash contents of biomasses tend to be much lower than coals used in coke mixtures. In this way, the insertion of biomass improves the coke ash balance, with a direct reflection on the drop in fuel consumption in the blast furnace. For each $1 \%$ reduction in ash in coke, $7 \mathrm{~kg} / \mathrm{t}$ hot metal is saved in coke rate practiced in the blast furnace (Silva, 2016). In addition, the low ash content of biomass is interesting for the coking process, since there is a decrease in tar formation.
Some additives can improve the coking capacity of a coal mixture and, therefore, can partially reduce the negative effects of biomass additions. This can be seen in figure 7 . 

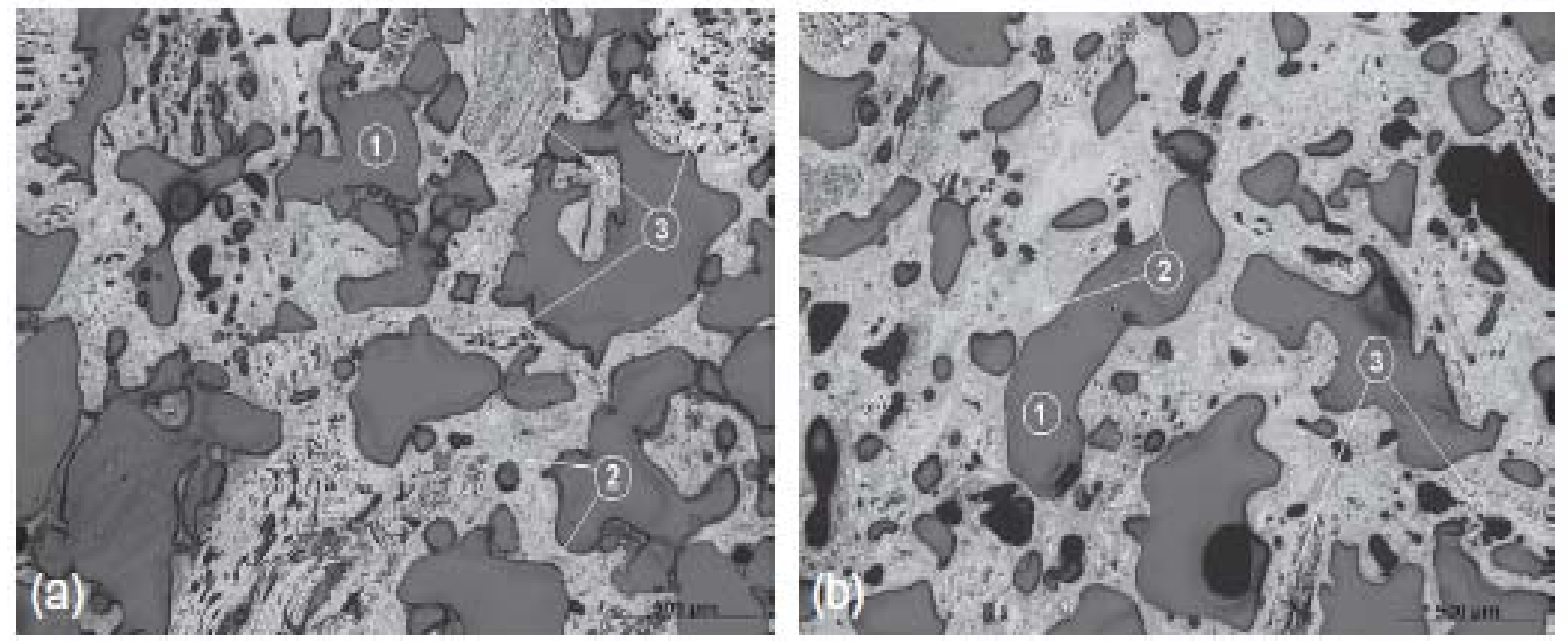

Figure 7: Biocoque optical micrographs: (a) coke with 10\% charcoal; (b) coke with $10 \%$ charcoal and an additive. 1-Voids; 2-coke matrix; 3-particles of charcoal (Mathieson, 2015)

The left side micrograph (a) refers to biocoque obtained without the addition of an additive, showing that surfaces of residual biomass particles are poorly assimilated in the coke matrix, evidenced by the welldefined limits of inclusions. The encapsulation of charcoal particles in the coke matrix was considerably improved when $2 \%$ of an organic additive was added to the mixture (b). CRI and CSR also tend to improve since the addition of an additive reduce the reactivity of coke (Mathieson, 2015).

These presented studies show that biocoque, coke produced with the addition of biomass, can be an adequate substitute for conventional fossil fuels with the potential to reduce $\mathrm{CO}_{2}$ emissions and reduce costs in the steel industry.

\section{d) Environmental Evaluation}

Environmental changes has become one of the most important issues in global politics. The Kyoto
Protocol, introduced in 1997, was the first international agreement to reduce greenhouse gases. The Paris agreement, signed in 2015 and valid since November 2016, determined an increase in the planet's temperature by $2^{\circ} \mathrm{C}$ by 2100 . This agreement was ratified by 179 countries that were in different stages of implementation and development of their environmental policies. Countries that have ratified the agreement recognize that the need to take action against climate change will imply accelerated policies and regulations that inevitably affect the industrial competitiveness of all nations and their respective economies. In parallel, several countries have set their own targets for reducing emissions. Table 3 shows some goals presented by countries in COP 21 for reducing greenhouse gas emissions.

Table 3: Goals are set by some countries to reduce greenhouse gas emissions (IRENA, 2020)

\begin{tabular}{|c|c|}
\hline Countries & Goals \\
\hline Australia & 5-25\% lower than 2000, until 2020 \\
\hline Brazil & 37\% lower than 2005 until 2025 and 43\% until 2030 \\
\hline Canada & 17\% lower than 2005, until 2020 \\
\hline China & 20-25\% reduction in emissions per unit of GDP from 2005, until 2020 \\
\hline European Union & Reduce 20\% until 2020, 40\% until 2030 and 80-95\% until 2050 \\
(compared with 1990)
\end{tabular}

Even with all these goals set by the countries, it will still be difficult to reach the global goal. The effort will have to be greater, and each contribution can be useful. Therefore, replacing fossil fuels with biomass in the steel industry will be interesting to help in this process. Thus, it will be presented how much it is possible to contribute with the partial replacement of coal in the cokemaking.
According to Sathler (2017), a Brazilian steel company in 2016 had an average coke rate and injection rate of, respectively, $295 \mathrm{~kg} / \mathrm{t}$ of hot metal and $188 \mathrm{~kg} / \mathrm{t}$ of hot metal. For Silva (2016), it is necessary around 1.2tons of coal to produce 1 ton of coke, therefore, for this situation, the consumption of I coal to produce 1 ton of hot metal is $188 \mathrm{~kg}$ in $\mathrm{PCl}$ and $354 \mathrm{~kg}$ of 
coal in coke. Consider equation 1 presented by Carvalho (2003):

$$
1 \mathrm{C}+0.5 \mathrm{O}_{2}+1.88 \mathrm{~N}_{2}=0.9 \mathrm{CO}_{2}+0.1 \mathrm{CO}+1.88 \mathrm{~N}_{2}
$$

Doing a simple stoichiometric calculation, it is possible to say that burning 1 ton of carbon produces 3.3 tons of $\mathrm{CO}_{2}$. It is possible to find in the literature several characterizations of coal with an average carbon content of $85 \%$. Concluding, $542 \mathrm{~kg}$ of coal have $460 \mathrm{~kg}$ of carbon, and its burning emits $1520 \mathrm{~kg}$ of $\mathrm{CO}_{2}$, that is, the emission in a blast furnace process reaches $1520 \mathrm{~kg} / \mathrm{t}$ of hot metal. Considering only the share of emissions from coke, this value would be $1168.2 \mathrm{~kg} / \mathrm{t}$ of hot metal.

The main question is how much $\mathrm{CO}_{2}$ can be avoided with the use of biomass in coal mixtures for cokemaking.

Researches developed by Silva (2008), 8 Campos (2018), Suopajärvi (2017), among others, analyzing the use of biomass in coke production, point out that it is possible to use an average of $6 \%$ of the biomass in coal mixture, producing coke with qualities and requirements to be used in a blast furnace. Therefore, if we consider the data presented above (354kg of coking coal per ton of hot metal), replacing $6 \%$ of coal used in coke production by biomass, there would be a decrease of $22 \mathrm{~kg}$ of coal per ton of hot metal produced. Finally, the contribution of coke burning to $\mathrm{CO}_{2}$ emissions in a blast furnace would be $1095.6 \mathrm{~kg}$ of $\mathrm{CO}_{2} / \mathrm{t}$ of hot metal, a decrease of $72.6 \mathrm{~kg}$ of $\mathrm{CO}_{2} / \mathrm{t}$ of hot metal.

When considering world production, this value can be significant. According to the World Steel Association (2021), hot metal production in 2019 reached 1.2 billion tons, that is, considering that all hot metal was produced via a coke blast furnace and that $6 \%$ of the coking coal was replaced by biomass, around 87 million tonnes of $\mathrm{CO}_{2}$ emissions would be avoided in one year.

Obviously, these numbers are just to provoke reflection and point some numbers of the use of biomass in the coke production. Other factors must be analyzed for use, but it is a fact that environmental restrictions are increasingly demanding, and the steel industry must adapt to meet the environmental schedule and show that it is a strong sector, which aims a sustainable production.

\section{ili. Conclusions}

The addition of biomass in coal mixture can be used in a certain limit. Researches shows that an average quantity is around 6\%, without an expressive change in coke quality. The quantity used can vary according to the granulometry and type of biomass, which case presented show the differences.
The Di decrease with the increase of biomass in the mixture. This was associated with the quantity of inert content, which influences in the mechanical resistance. In addition, the coarse granulometry decreases more than the fines one.

The addition of biomass to the coal mixture is still considerably low, despite significantly influencing the cost and $\mathrm{CO}_{2}$ emission, since it acts with a lower CRS and a higher $\mathrm{CRI}$ in relation to the coke conventionally used by steel companies.

In terms of the environment, the use of $6 \%$ of biomass in the blast furnace is capable of reducing $\mathrm{CO}_{2}$ emissions by up to $6.21 \%$ per ton of hot metal, according to the calculations carried out, and despite being a low value; it causes an immense effect when considering the annual 87 million tonnes of reduced $\mathrm{CO}_{2}$ emissions.

Is necessary to optimize the processes for obtaining, transporting and stocking biomass so that they can compete with fossil fuels as a raw material for the cokemaking. Cooperation between industrial sectors and agribusiness is essential. The development of alternatives is extremely important in order to guarantee an increase in the useful life of the coke plant.

\section{ACKNOWLEDGEMENT}

The authors acknowledge CAPES, CNPq, REDEMAT, UFOP, EcoEnviroX and, all that contributed to this research.

\section{References Références Referencias}

1. AISE Steel Foundation. The making, shaping and treating of steel, Ironmaking volume.11.ed. Pittsburgh, PA: The AISE Steel Foundation, 1999. 780p. ISBN: 0-930767-03-9.

2. BABICH, A., SENK, D., SOLAR, J., MARCO, I. Efficiency of biomass use for blast furnace injection. ISIJ International, v. 59, n.12, p.2212-2219, 2019.

3. CAMPOS, A.M.A., ASSIS, P.S., NOVACK, K.M. Aspectos Econômicos E Ambientais Do Uso De Biomassas $\mathrm{Na}$ Siderurgia, p. 21-32. In: $48^{\circ}$ Seminário de Redução de Minérios e Matériasprimas, São Paulo, 2018.

4. CARVALHO, F.C. Disponibilidade de Resíduos Agroindustriais e do Beneficiamento de Produtos Agrícolas. Informações Econômicas, v.22, n.12, p.31-46. 1992.

5. CARVALHO, L.A.L., CAMPOS, A.M.A., ASSIS, P.S. Quality evaluation of metallurgical coke produced with sawdust and different mixture of coal. REM, Int. Eng. J., Ouro Preto, v. 74, n. 2, p. 219-223, 2021.

6. EMBRAPA. Balanço Energético e "Sequestro" de Carbono em Culturas Oleaginosas. Campina Grande, 2007. Available in: $<$ https://ainfo.cnptia. 
embrapa.br/digital/bitstream/CNPA/20778/1/DOC16 7.PDF > . Access in: 25/03/2021.

7. GARSIDE, M. Coke production Worldwide. Statista. 2019. Available in: <https://www.statista.com/ statistics/267891/global-coke-production-since1993/>. Access in 09/04/2021.

8. HOLAPPA, L. 2020. A General Vision for Reduction of Energy Consumption and $\mathrm{CO} 2$ Emissions from the Steel Industry. Metals, v. 10, n. 9, p. 1117-1138, 2020.

9. IRENA. Reaching zero with renewables: Eliminating $\mathrm{CO}_{2}$ emissions from industry and transport in line with the $1.5{ }^{\circ} \mathrm{C}$ climate goal, International Renewable Energy Agency, Abu Dhabi, 2020. Available in: <https://www.irena.org/-/media/Files/ IRENA/Agency/Publication/2020/Sep/IRENA_Reachi ng_zero_2020.pdf $>$. Access in: 8/04/2021.

10. KUBOTA, Y. et al.; Effects of coal inertinite size on coke strength. ISIJ International, v.48, n`5, p.563571, 2008.

11. LIZIERO, G. CARLOS, A. MARLON, A. DORNELAS, P. DIAS, N. MOREIRA, V. 2017. Avaliação da adição de biorredutor na mistura de carvões minerais na qualidade do coque metalúrgico, $V$ Congresso Brasileiro de Carvão Mineral. Criciúma, SC, Brasil.

12. MATHIESON, J. SOMERVILLE, M.A. DEEV, A. JAHANSHAHI, S. (2015). Utilization of biomass as an alternative fuel in ironmaking. 10.1016/B978-178242-156-6.00019-8

13. MOURÃO, Marcelo B. Introdução a siderurgia. 2.ed. São Paulo: Associação Brasileira de Metalurgia Materiais e Mineração, 2011. 428p.

14. MOUSA E, WANG C, RIESBECK J, LARSSON M. 2016.Biomass applications in iron and steel industry: An overview of challenges and opportunities. Renewable and Susteainable Energy Reviews, v. 65, p. 1247-1266, 2016.

15. NOLDIN, J.H., CONSTRUCCI, M.A., D'ABREU, J. C. Tecnored process-High potential in use differente kinds of solid fuel. Materials Research, v. 8, n.4, p. 447-451, 2005.

16. ORTH, A., ANASTASIJEVIC, N., EICHBERGER, H., Low $\mathrm{CO} 2$ emission technologies for iron and steelmaking as well as titania slag production. Minerals Engineering, v. 20, n. 9, pp. 854-861, 2007.

17. QUAN, C.; GAO, N. Copyrolysis of Biomass and Coal: A Review of Effects of Copyrolysis Parameters, Product Properties, and Synergistic Mechanisms. BioMed Research International, v. 2016, p. 1-11, 2016.

18. RICKETTS, John A. History of Ironmaking. Warrendale: Iron \& Steel Society, 2000. 194p.

19. RIZZO, Ernandes M. S. Processo de Fabricação de Ferro-Gusa em Alto-Forno. São Paulo: Associação Brasileira de Metalurgia Materiais e Mineração, 2009. 278p.
20. SATHLER, Felipe; JUNIOR, Ramiro C. N.; PERDIGÃO, L. P.; RIBEIRO, E.C.; WASEN, L.A. Projeto CR298: Altas taxas de injeção de carvão $\mathrm{PCl}$ com baixo fuel rate nos altos-fornos da ArcelorMittal Tubarão, p. 159-169. In: 47 Seminário de Redução de Minérios e Matérias-primas, São Paulo, 2017.

21. SILVA, A. M. Estudo da utilização da biomassa em substituição parcial ao carvão mineral no processo de fabricação do ferro gusa em alto-forno. 2008. $147 \mathrm{f}$. These $(\mathrm{PhD})$ - Programa de pós-graduação em engenharia Mecânica, Universidade Estaual Paulista. 2008.

22. SILVA, A. M. et al. Estudo Da Utilização Da Biomassa Em Substituição Parcial Ao Carvão Mineral Na Fabricação Do Coque na Coqueira da Csn. Tecnologia em Metalurgia e Materiais, v. 5, n. 1, p. $40-45,2008$

23. SILVA, G.L.R. Utilização de Moinha de Bioredutor e Pneu Inservível na Produção de Coque Metalúrgico. 2016. 188 f. Tese (Doutorado) - Programa de pósgraduação em engenharia de materiais, Universidade Federal de Ouro Preto. 2016a.

24. SILVA, G.L.R., BRAGA, E.M.H., ASSIS, P.S., QUINTAS, A.C.B., DORNELAS, P.H.G., MOURA, L.C.A., SOUZA, R.D.S., 2016. Utilização de finos de carvão vegetal para produção de biocoque metalúrgico. ABM Week. Rio de Janeiro, RJ, Brasil.

25. SUOPAJÄRVI, H., KEMPPAINEN, A., HAAPAKANGAS, J., Fabritius, T. Extensive review of the opportunities to use biomass-based fuels in iron and steelmaking processes. Journal of Cleaner Production, v.148, p.709-734, 2017.

26. WORLD STEEL ASSOCIATION. Steel Statistical yearbook 2020 concise version. Available in: $<$ https://www.worldsteel.org/en/dam/jcr:5001dac80083-46f3-aadd-35aa357acbcc/SSY\%25202020 concise\%2520version.pdf $>$. Accessed in: April $15^{\text {th }}$ 2021. 